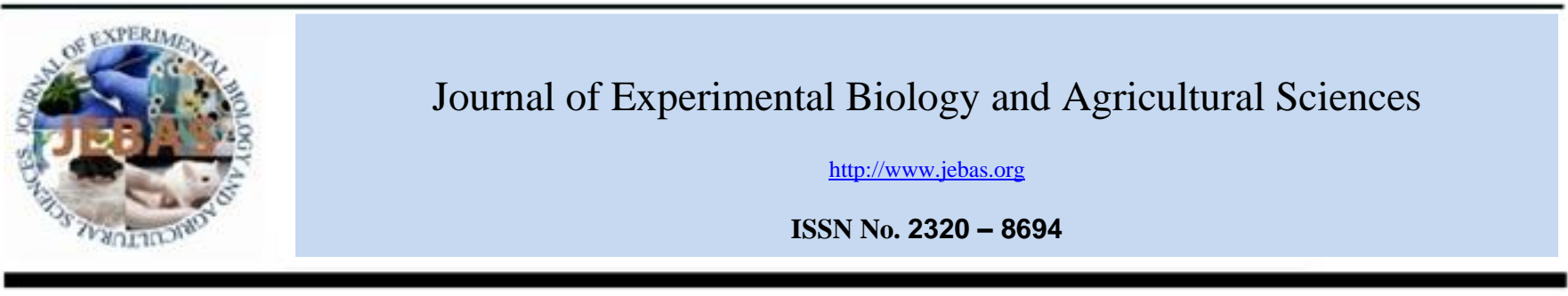

\title{
GROWTH AND YIELD RESPONSE OF SWEET POTATO TO DIFFERENT TILLAGE METHODS AND PHOSPHORUS FERTILIZER RATES IN GHANA
}

\author{
G. Dumbuya ${ }^{1, *}$, J. Sarkodie-Addo ${ }^{2}$, M. A. Daramy ${ }^{3}$ and M. Jalloh ${ }^{4}$ \\ ${ }^{1}$ Sierra Leone Agricultural Research Institute/ Njala Agricultural Research Centre, Njala, Sierra Leone \\ ${ }^{2}$ Department of Crop and Soil Sciences, Faculty of Agriculture, Kwame Nkrumah University of Science and Technology, Kumasi, Ghana \\ ${ }^{3}$ Sierra Leone Agricultural Research Institute/ Rokupr Agricultural Research Centre, Rokupr, Sierra Leone \\ ${ }^{4}$ Sierra Leone Agricultural Research Institute/Kenema Forestry and Tree Crops Research Centre, Sierra Leone
}

Received - May 30, 2016; Revision - July 20, 2016; Accepted - August 20, 2016

Available Online - August 31, 2016

DOI: http://dx.doi.org/10.18006/2016.4(5).475.483

\author{
KEYWORDS \\ Sweet potato \\ Tillage \\ Phosphorus fertilizer \\ Growth \\ Yield
}

\begin{abstract}
A field experiment was conducted during the major cropping season of 2014 at the Plantation Section of the Department of Crop and Soil Sciences, Kwame Nkrumah University of Science and Technology, Ghana to evaluate the effect of tillage and different application rates of phosphorus fertilizer on the growth and yield of sweet potato variety Okumkom. The tillage methods are ridge \& mound while the different rates of phosphorus fertilizers are 0, 30, 60, 90 and $120 \mathrm{~kg} \mathrm{P}_{2} \mathrm{O}_{5} /$ ha in triple superphosphate $\left(46 \% \mathrm{P}_{2} \mathrm{O}_{5}\right)$ form. Factorial experiment was used and treatments were arranged in a Randomized Complete Block Design with three replications. All the treatments were supplemented by $30 \mathrm{~kg} \mathrm{~N} / \mathrm{ha}$ in the form of Urea $(46 \% \mathrm{~N})$. Results of this study indicated that plant growth was not significantly affected by tillage, but root yield was affected significantly with ridging produced the highest root yield. Further, highest growth and yield was observed from the $60 \mathrm{~kg} \mathrm{P}_{2} \mathrm{O}_{5} /$ ha treatment.
\end{abstract}

* Corresponding author

E-mail: gibrildumbuya@gmail.com (Gibrilla Dumbuya)

Peer review under responsibility of Journal of Experimental Biology and Agricultural Sciences.

Production and Hosting by Horizon Publisher India [HPI] (http://www.horizonpublisherindia.in/).

All rights reserved.
All the article published by Journal of Experimental Biology and Agricultural Sciences is licensed under a Creative Commons Attribution-NonCommercial 4.0 International License Based on a work at www.jebas.org.

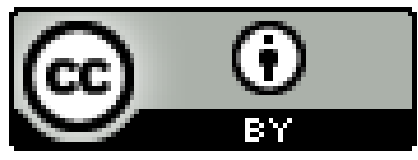




\section{Introduction}

Sweet potato (Ipomoea batatas (L) Lam) is a tuber rootbearing vegetable species grown in tropical areas for either domestic or industrial uses. Root of sweet potato is rich in vitamin A, B6, C, riboflavin, copper, pantothenic and folic acid (Abd El-Baky et al., 2009). These tubers have great food quality and an excellent source of anti-oxidants and carotenes (Woolfe, 1992). According to Berberich et al. (2005), the crop has several industrial uses, including medicinal purposes; use for treating diabetes, hookworms, ulcer and internal bleeding.

China is the highest producer of sweet potato $(82,474,410$ tonnes) and making Asia the leading producer of sweet potato in the world (FAO, 2012). In Africa, Nigeria (2,883,408 tonnes) ranked after Uganda while Ghana produces 90,000 tonnes on 65,000 ha area (FAOSTAT, 2006). In Ghana, sweet potato is produced exclusively by peasant farmers. Consequently, the potential contribution of this crop toward food security in Ghana is underestimated as there is a huge gap between potential yield and the yield of peasant farmers (CRI, 2002). Factors responsible for farmer's low yields are inappropriate tillage practices and lack of knowledge on the type and rate of fertilizer needed by the crop. Appropriate tillage systems improve aeration, water transmission, root growth and nutrient uptake (Ojeniyi, 1992; FAO, 2000). Farmers use various tillage methods for sweet potato production, among these small scale farmers' plant local varieties using the flat method of tillage while farmers who have adopted improved varieties plant them on mounds or ridges. Janssens (2001) reported that mound planting provides favorable conditions for the formation of tuberous roots, therefore it can be concluded that growing on mounds is better than the growing on ridges, particularly in heavy soils. Further, Ennin et al. (2003) concluded that planting on ridges is preferable as it leads to increase in the crop`s yield due to increased plant population density which facilitate weed suppression and reduce crop-weed competition.

One of the most important nutrients for many plant species including sweet potato is Phosphorus (P) (El Sayed Hameda et al., 2011). $P$ acts as an important part of many organic compounds in plants and these are vital for metabolic processes, blooming and root development (El Sayed Hameda et al., 2011). In many crop production systems where $P$ application is unavoidable in order to increase plant productivity, despite the huge addition of P-fertilizers, very little amount of $\mathrm{P}$ is available to the plants as most is converted to unavailable form by reaction with soil constituents (Marschner, 1995). This explains the dearth of literature on the use of P fertilizer to sweet potato and why FAO (2005) showed that sweet potato yield is not affected when $\mathrm{P}$ is eliminated during cultivation. In spite of $\mathrm{P}$ fixation, several authors including Were et al. (2003), Hassan et al. (2005) have observed favourable response of sweet potato to application of $P$ fertilizer. In view of the above findings, this study was conducted to ascertain the best tillage practices and optimum rate of $\mathrm{P}$ fertilizer application for the growth and root yield of sweet potato in Ghana.

\section{Materials and Methods}

\subsection{Description of the Study Area}

Field study was conducted at the Plantation Section of the Crop and Soil Sciences Department, Kwame Nkrumah University of Science and Technology (KNUST), Kumasi, Ghana from June to October 2014. Kumasi is in the semideciduous forest vegetation Zone of Ghana on latitude $06^{\circ}$ $43^{\circ \mathrm{N}}$ and longitude $01^{\circ} 33^{\circ \mathrm{C}} \mathrm{W}$ and $356 \mathrm{~m}$ above sea level (Asiamah, 1998). Annual rainfall on average is $1422.4 \mathrm{~mm}$ and relative humidity on average varied from $83.88 \%$ (09 hours GMT) during the major and minor rainy seasons to $58.42 \%$ (15 hours GMT) during the dry season for 2014 (Meteorological Department, KNUST, 2014). The annual average maximum and minimum temperature was $31.59^{\circ} \mathrm{C}$ and $22.09^{\circ} \mathrm{C}$ respectively. During the study period, mean daily maximum and minimum temperatures were $29.01^{\circ} \mathrm{C}$ and $21.32^{\circ} \mathrm{C}$, respectively, for the major rainy season while in the minor rainy season they were $31.85^{\circ} \mathrm{C}$ and $22.34^{\circ} \mathrm{C}$, respectively. During the major and minor rainy season of the study period, total rainfall was $466.55 \mathrm{~mm}$ and $317.85 \mathrm{~mm}$, respectively. During the major season, the relative humidity varied from $77.84 \%$ (09 hours GMT) to $51.34 \%$ (15 hours GMT) whereas in the minor season, it varied from $83.67 \%$ (09 hours GMT) to $59.17 \%$ (15 hours GMT) (Meteorological Department, KNUST, 2014).

\subsection{Soil sampling and analysis}

Prior to the experiment, soil samples were collected from the site at depths of $0-15 \mathrm{~cm}$ and $15-30 \mathrm{~cm}$ with the aid of a soil auger, mallet and core sampler. These samples were taken to the laboratory for analysis in order to determine their physicochemical properties. Before the analysis, the samples were airdried and later sieved with a $2 \mathrm{~mm}$ mesh sieve. The samples were then analyzed separately for organic carbon, total nitrogen, exchangeable potassium, available phosphorus, soil $\mathrm{pH}$ and bulk density. Walkley \& Black (1934) method was used to determine organic carbon, while total nitrogen was determined by using the modified Kjeldahl method (Bremmer \& Mulvaney, 1982). Exchangeable $\mathrm{K}$ was determined with the flame photometer method (Hanway \& Heidel, 1952) and Bray1 solution was used for extracting the available phosphorus (Anderson \& Ingram., 1993). Soil pH was measured in 1:2.5 soils to water suspension by the use of a $\mathrm{pH}$ meter and bulk density was determined using the formula of Cresswell \& Hamilton (2002).

\subsection{Experimental setup}

The trial was setup as a $2 \times 5$ factorial experiment with treatments arranged in Randomised Complete Block Design (RCBD) replicated three times. Tillage methods (ridges and 
mounds) and $\mathrm{P}$ fertilizer (triple superphosphate) application (0, $30,60,90$ and $120 \mathrm{~kg} \mathrm{P}_{2} \mathrm{O}_{5}$ per hectare) were the studied factors.

\subsection{Preparation of ridges and mounds}

The site was cleared manually by slashing with cutlasses, ploughed and harrowed with a tractor and later leveled. It was then divided into two halves, one for ridges and the other for mounds. The tools used for the construction of the ridges and mounds are hoes and spades. The dimension of the ridges was $2 \mathrm{~m}$ long $\times 1 \mathrm{~m}$ wide $\times 0.3 \mathrm{~m}$ high, while that for the mounds was $0.3 \mathrm{~m}$ high $\times 0.5 \mathrm{~m}$ wide at the base. In each plot, there were 4 ridges or 24 mounds spaced at $0.5 \mathrm{~m}$ from each other. There was $0.5 \mathrm{~m}$ spacing between plots and $1 \mathrm{~m}$ spacing between replication.

2.5 Preparation and planting of sweet potato cuttings

Tip cuttings that were $30 \mathrm{~cm}$ long with six nodes were cut from the early maturing variety Okumkom that was obtained from the Crops Research Institute (CRI). Following the procedure of Amoah (1997), six cuttings were planted per ridge at a spacing of $1 \mathrm{~m} \times 0.8 \mathrm{~m}$, whereas one cutting was planted per mound at a spacing of $1 \mathrm{~m} \times 0.5 \mathrm{~m}$, giving 24 plants in each plot. Planting was done by inserting half to two-thirds long of each cutting into the soil inclined at an angle of about $45^{\circ}$ with nodes pointing upwards.

\subsection{Agronomic operations}

The different rates of triple superphosphate $\left(46 \% \mathrm{P}_{2} \mathrm{O}_{5}\right)$ and 30 $\mathrm{kg} \mathrm{N} / \mathrm{ha}$ in the form of urea $(46 \% \mathrm{~N})$ were applied by side band placement at 2 weeks after planting (WAP). In order to keep the experimental site free from weeds, weeding was carried out by hand at 2 WAP (before fertilizer application) and 3 weeks after fertilizer application. Two watering cans of water were supplied when necessary per plot. Pests were controlled with the application of $0.10 \mathrm{ml}$ of Lambda master $2.5 \%$ E.C. (Lambda-Cyhalothrin, $9.8 \%$ ) in 11 liters of water at 3 weeks intervals after planting using a Knapsack sprayer. Harvesting was done 120 days after planting (DAP) by digging the tubers out of the ridges and mounds using a hand hoe.

\subsection{Data collection and analysis}

Five plants from each plot were selected and tagged for data collection. Data were collected on vine length, vine girth, number of branches and number of leaves per plant at 1 and 2 months after fertilizer application. The yield data were collect at 120 DAP, these were based on the total number of roots per plant, root yield per plant, total number of marketable and nonmarketable root per plant, weight of marketable and nonmarketable roots per plant, dry matter content and root yield per hectare. Total numbers of roots per plant, number of marketable and non-marketable roots per plant were determined by counting the harvested roots from five tagged plant in all the plots. Medium to large size roots were considered to be marketable and those ranging from small to very small were considered to be non-marketable.

Root yield per plant, marketable and non-marketable root yield per plant were determined by weighing the roots (in $\mathrm{kg}$ ) harvested from the five tagged plants in each plot. Selected root samples from the five tagged plants per plot were washed, peeled and chopped into smaller fragments for dry matter determination; $50 \mathrm{~g}$ of the chopped samples were weighed using an electronic balance and then freeze-dried for 72 hours after which they were removed and the dry weight was taken. The dry matter content was then computed for each treatment as follows:

$$
\text { Dry matter content }(\%)=\frac{\text { Dry weight }(\mathrm{DW})}{\text { Fresh weight }(\mathrm{FW})} \times 100
$$

Root yield per hectare was determined from a $5 \mathrm{~m}^{2}$ area and extrapolated to yield per hectare.

The economic viability of each treatment was determined by subtracting the total input cost from the total revenue. The total input costs include fertilizer, cost of transporting fertilizer to the farm and cost of applying fertilizer, while the total revenue is the price per kilogram value of the root yield per hectare ( $\mathrm{t} / \mathrm{ha}$ ) for each treatment using the farm gate price of sweet potato (value in Ghana cedis).

Analysis of Variance (ANOVA) was conducted on the collected data using GenStat statistical package $12^{\text {th }}$ edition. Treatment means were separated using Least Significant Difference (LSD) at $5 \%$ probability level.

\section{Results}

3.1 Soil characteristic of the experimental field

According to the soil physio-chemical analysis (Table 1), the soil is sandy loam, having an average of $82.60 \%$ sand, $3.98 \%$ silt and $13.41 \%$ clay. It is slightly acidic with low levels of $\mathrm{N}$ and $\mathrm{P}$, but moderate amount of $\mathrm{K}$ content. It also contains inadequate organic carbon $(<2 \%)$ and bulk densities of 1.45 and $1.46 \mathrm{~g} / \mathrm{cm}^{3}$.

\subsection{Growth parameters}

The results concerning growth parameters as affected by tillage method and phosphorus fertilizer application are presented in Table 2. The effect of tillage method was not found significant on any measured growth parameters at both sampling periods. The application of phosphorus fertilizer had no effect on vine length, vine girth and number of branches, but significantly ( $P$ $<0.05)$ affected the number of leaves at 30 days after fertilizer application. 
Table 1 Soil physio-chemical properties of the experimental site

\begin{tabular}{|l|c|c|}
\hline Soil property & $\mathbf{0 - 1 5} \mathbf{~ c m}$ & $\mathbf{1 5}-\mathbf{3 0} \mathbf{~ c m}$ \\
\hline $\mathrm{pH}\left(\mathrm{x}: \mathrm{y}, \mathrm{H}_{2} \mathrm{O}\right)$ & 5.98 & 5.92 \\
\hline Total nitrogen $(\%)$ & 0.09 & 0.05 \\
\hline Available phosphorus $(\mathrm{mg} / \mathrm{kg})$ & 3.19 & 2.20 \\
\hline Exchangeable potassium $(\mathrm{Cmol} / \mathrm{kg})$ & 0.14 & 0.20 \\
\hline Organic carbon $(\%)$ & 1.48 & 0.61 \\
\hline Bulk density $\left(\mathrm{g} \mathrm{cm}^{-3}\right)$ & 1.45 & 8.46 \\
\hline Sand $(\%)$ & 84.30 & 4.07 \\
\hline Silt $(\%)$ & 3.90 & 15.03 \\
\hline Clay $(\%)$ & 11.80 & Sandy loam \\
\hline Texture & Sandy loam & \\
\hline
\end{tabular}

Amongst various tested combinations, highest number of leaves (151.3) was associated with $60 \mathrm{~kg} \mathrm{P}_{2} \mathrm{O}_{5} / \mathrm{ha}$ and this was significantly higher than those of $30 \mathrm{~kg} \mathrm{P}_{2} \mathrm{O}_{5} / \mathrm{ha}$ (111.6) and the control (93.0). Further, the numbers of leaves at 90 and 120 $\mathrm{kg} \mathrm{P}_{2} \mathrm{O}_{5} / \mathrm{ha}$ were significantly higher than the control. No significant effect was observed at 60 days after fertilizer application following $\mathrm{P}$ fertilizer application (Table 2). However, there was no significant interaction effect of tillage methods and phosphorus fertilizer rates for all the growth parameters studied.

\subsection{Yield and yield components}

\subsubsection{Total number of roots per plant}

Total number of roots per plant was not significantly affected by tillage method but a significant effect $(\mathrm{P}<0.05)$ of phosphorus fertilizer was reported in the present study (Table 3). Among various treatments, application of $60 \mathrm{~kg} \mathrm{P}_{2} \mathrm{O}_{5} / \mathrm{ha}$ produced the highest number of tubers (5.70) and this was significantly higher than the yield associated with $120 \mathrm{~kg} \mathrm{P} / \mathrm{ha}$ (4.17) and the control (3.77) while $30 \mathrm{~kg} \mathrm{P} / \mathrm{ha} \mathrm{(5.10)} \mathrm{and} 90 \mathrm{~kg}$ $\mathrm{P}_{2} \mathrm{O}_{5} /$ ha (4.90) yielded significantly more than the control but other treatment did not show any significant effects on the number of roots.

\subsubsection{Root yield per plant and Dry matter content}

Results of root yield per plant and dry matter content (Table 3) was significant only for phosphorus fertilizer application but did not show any significant effect for tillage methods. Root yield per plant was highest $(0.858 \mathrm{~kg})$ at $\mathrm{P}$ application rate of $60 \mathrm{~kg} \mathrm{P}_{2} \mathrm{O}_{5} /$ ha which was significantly higher than those of 30 $\mathrm{kg} \mathrm{P}_{2} \mathrm{O}_{5} / \mathrm{ha}(0.590 \mathrm{~kg})$ and control $(0.525 \mathrm{~kg})$. Application rates of $90 \mathrm{~kg} \mathrm{P}_{2} \mathrm{O}_{5} / \mathrm{ha}(0.782 \mathrm{~kg})$ and $120 \mathrm{~kg} \mathrm{P}_{2} \mathrm{O}_{5} / \mathrm{ha}(0.753 \mathrm{~kg})$ gave significantly higher yield per plant than the control but the $30 \mathrm{~kg} \mathrm{P} \mathrm{O}_{5} / \mathrm{ha}(0.590 \mathrm{~kg})$ and the control were statistically similar. Root dry matter content at $60 \mathrm{~kg} \mathrm{P}_{2} \mathrm{O}_{5} / \mathrm{ha}(36.42 \%)$ was significantly higher than all the other treatments, except for the $90 \mathrm{~kg} \mathrm{P}_{2} \mathrm{O}_{5} / \mathrm{ha} \mathrm{(35 \% )} \mathrm{as} \mathrm{shown} \mathrm{in} \mathrm{Table} 3$.

Table 2 Effect of tillage method and phosphorus fertilizer application on growth parameters of sweet potato at two sampling periods.

\begin{tabular}{|c|c|c|c|c|c|c|c|c|}
\hline Treatments & \multicolumn{2}{|c|}{ Vine length $(\mathrm{cm})$} & \multicolumn{2}{|c|}{ Vine girth $(\mathrm{cm})$} & \multicolumn{2}{|c|}{ Number of branches } & \multicolumn{2}{|c|}{ Number of Leaves } \\
\hline \multicolumn{9}{|c|}{ Tillage method } \\
\hline & $30 \mathrm{DAF}$ & $60 \mathrm{DAF}$ & $30 \mathrm{DAF}$ & $60 \mathrm{DAF}$ & 30DAF & $60 \mathrm{DAF}$ & $30 \mathrm{DAF}$ & $60 \mathrm{DAF}$ \\
\hline Mound & 276.2 & 323.5 & 0.471 & 0.596 & 5.59 & 9.12 & 116.3 & 147.9 \\
\hline Ridge & 288.1 & 332.9 & 0.481 & 0.632 & 6.11 & 10.67 & 131.1 & 177.2 \\
\hline $\operatorname{LSD}(5 \%)$ & NS & NS & NS & NS & NS & NS & NS & NS \\
\hline SED & 9.13 & 10.59 & 0.02 & 0.02 & 0.80 & 1.46 & 9.80 & 16.85 \\
\hline \multicolumn{9}{|c|}{$\mathrm{P}$ fertilizer $\left(\mathrm{kgP}_{2} \mathrm{O}_{5} / \mathrm{ha}\right)$} \\
\hline Control & 265.0 & 304.5 & 0.407 & 0.553 & 4.20 & 5.97 & $93.0 \mathrm{c}$ & 121.6 \\
\hline 30 & 279.2 & 323.3 & 0.453 & 0.623 & 5.10 & 9.10 & $111.6 \mathrm{bc}$ & 170.9 \\
\hline 60 & 292.8 & 344.2 & 0.517 & 0.653 & 7.50 & 13.33 & $151.3 \mathrm{a}$ & 193.1 \\
\hline 90 & 288.8 & 339.5 & 0.507 & 0.620 & 6.40 & 10.33 & $133.5 \mathrm{ab}$ & 174.5 \\
\hline 120 & 284.9 & 329.3 & 0.497 & 0.620 & 6.03 & 10.73 & $129.1 \mathrm{ab}$ & 152.8 \\
\hline LSD (5\%) & NS & NS & NS & NS & NS & NS & 32.5 & NS \\
\hline SED & 14.44 & 16.74 & 0.03 & 0.03 & 1.26 & 2.31 & 15.49 & 26.64 \\
\hline Tillage $\times P$ & NS & NS & NS & NS & NS & NS & NS & NS \\
\hline $\mathrm{CV}(\%)$ & 8.9 & 8.8 & 13.9 & 9.1 & 37.5 & 40.5 & 21.7 & 28.4 \\
\hline
\end{tabular}

NS - not significant from individual application; means having the same letter(s) in column, are not significantly different at $\mathrm{P}<0.05$ separated using the LSD; DAF - days after fertilize application. 
Table 3 Total number of roots, root yield per plant and dry matter content of sweet potato as affected by tillage methods and phosphorus fertilizer .

\begin{tabular}{|lccc|}
\hline Treatments & $\begin{array}{c}\text { Total no. of roots per } \\
\text { plant }\end{array}$ & $\begin{array}{c}\text { Root yield per plant } \\
(\mathbf{k g})\end{array}$ & $\begin{array}{c}\text { Dry matter content of tuber } \\
\text { roots (\%) }\end{array}$ \\
\hline Tillage method & $4.73^{\mathrm{a}}$ & $0.651^{\mathrm{a}}$ & $34.51^{\mathrm{a}}$ \\
\hline Mound & $4.72^{\mathrm{a}}$ & $0.752^{\mathrm{a}}$ & $35.01^{\mathrm{a}}$ \\
\hline Ridge & $\mathrm{NS}$ & $\mathrm{NS}$ & $\mathrm{NS}$ \\
\hline $\mathrm{LSD}(5 \%)$ & 0.28 & 0.05 & 0.50 \\
\hline SED & & & $33.70^{\mathrm{b}}$ \\
\hline P fertilizer $\left(\mathrm{kg} \mathrm{P}_{2} \mathrm{O}_{5} /\right.$ ha) & $3.77^{\mathrm{c}}$ & $0.525^{\mathrm{c}}$ & $33.97^{\mathrm{b}}$ \\
\hline Control & $5.10^{\mathrm{ab}}$ & $0.590^{\mathrm{bc}}$ & $36.42^{\mathrm{a}}$ \\
\hline 30 & $5.70^{\mathrm{a}}$ & $0.858^{\mathrm{a}}$ & $35.00^{\mathrm{ab}}$ \\
\hline 60 & $4.90^{\mathrm{ab}}$ & $0.782^{\mathrm{ab}}$ & $34.72^{\mathrm{b}}$ \\
\hline 90 & $4.17^{\mathrm{bc}}$ & $0.753^{\mathrm{ab}}$ & 1.67 \\
\hline 120 & 0.94 & 0.194 & 0.79 \\
\hline $\mathbf{L S D}(\mathbf{5 \%})$ & 0.44 & 0.09 & $\mathrm{NS}$ \\
\hline SED & $\mathrm{NS}$ & $\mathrm{NS}$ & 4.0 \\
\hline Tillage $\times \mathbf{P}$ & 16.4 & 22.8 & \\
\hline CV $(\%)$ & & & \\
\hline
\end{tabular}

NS - not significant from individual application; means having the same letter(s) in column, are not significantly different at $\mathrm{P}<0.05$ separated using the LSD

3.3.3 Total number of marketable and non-marketable roots per plant

Like other parameters, no significant difference on total number of marketable roots per plant was observed for tillage methods (table 4), but application of $\mathrm{P}$ fertilizer at $60 \mathrm{~kg}$ $\mathrm{P}_{2} \mathrm{O}_{5} /$ ha (4.63) gave significantly $(\mathrm{P}<0.001)$ more marketable roots than that of the control (3.20) and $120 \mathrm{~kg} \mathrm{P}_{2} \mathrm{O}_{5} / \mathrm{ha} \mathrm{(3.23).}$ Significantly higher marketable roots was also observed in the $30 \mathrm{~kg} \mathrm{P}_{2} \mathrm{O}_{5} / \mathrm{ha} \mathrm{(4.30)}$ and the $90 \mathrm{~kg} \mathrm{P}_{2} \mathrm{O}_{5} / \mathrm{ha} \mathrm{(4.03)} \mathrm{treatments}$ than for the control. Furthermore, table 4 revealed that there was no significant difference for both tillage methods and $\mathrm{P}$ fertilizer application on total number of non-marketable roots per plant.

\subsubsection{Marketable and non-marketable root yield per plant}

The results of marketable and non- marketable root yield of sweet potato as affected by tillage and phosphorus fertilizer application are presented in Table 4. Like other growth attributes, tillage method was also not significant $(\mathrm{P}>0.05)$ for marketable root yield per plant (Table 4). The response of sweet potato to the different level of phosphorus fertilizer for marketable root yield showed significant differences, in which the highest marketable yield $(0.833 \mathrm{~kg})$ was produced by the $60 \mathrm{~kg} \mathrm{P}_{2} \mathrm{O}_{5} /$ ha treatment and this was significantly higher than the control and $30 \mathrm{~kg} \mathrm{P}_{2} \mathrm{O}_{5} / \mathrm{ha}$ treatments. Marketable root yield was significantly lower in the control than the 90 and 120 $\mathrm{kg} \mathrm{P}_{2} \mathrm{O}_{5} /$ ha treatments. Both tillage methods and $\mathrm{P}$ fertilizer application did not affect $(\mathrm{P}>0.05)$ non-marketable root yield per plant (Table 4).

\subsubsection{Root yield per hectare}

Results for the influence of different tillage methods and phosphorus fertilizer application on sweet potato root yield per hectare are presented in Table 5. Sweet potato responded significantly $(\mathrm{P}<0.05)$ to both tillage methods and phosphorus fertilizer rates. Ridging produced significantly higher root yield than mounding. The highest root yield (15.82 t/ha) was associated with $60 \mathrm{~kg} \mathrm{P}_{2} \mathrm{O}_{5} / \mathrm{ha}$, and this was significantly higher than those of the control $(9.47 \mathrm{t} / \mathrm{ha})$ and $30 \mathrm{~kg} \mathrm{P}_{2} \mathrm{O}_{5} / \mathrm{ha}$ (12.18 t/ha). Furthermore, $90 \mathrm{~kg} \mathrm{P}_{2} \mathrm{O}_{5} / \mathrm{ha}(13.70 \mathrm{t} / \mathrm{ha})$ and 120 $\mathrm{kg} \mathrm{P}_{2} \mathrm{O}_{5} / \mathrm{ha}$ (12.97) also gave significantly higher yield than the control.

\subsection{Economic analysis}

According to the results in Table 5, ridge tillage method had significantly higher net return (GHc 19,150.00) over mounding (GHc 15,265.00). There was no significant difference for the different $\mathrm{P}$ fertilizer rates despite the $60 \mathrm{~kg}_{2} \mathrm{O}_{5} / \mathrm{ha}$ had the highest net return (GHc 21,251.00) than the control (GHc 13,654.00) (Table 5).

\section{Discussions}

4.1 Effect of tillage method and phosphorus fertilizer application on growth parameters of sweet potato

The non-significant effect of tillage methods on growth parameters (vine length, number of branches, vine girth and number of leaves) could be because both ridges and mounds were of the same height $(30 \mathrm{~cm})$. 
Table 4 Effects of tillage method and phosphorus fertilizer application on total number of marketable and non- marketable roots, marketable and non- marketable root yield per plant at harvest of sweet potato.

\begin{tabular}{|c|c|c|c|c|}
\hline Treatments & $\begin{array}{l}\text { Total No. of marketable } \\
\text { roots per plant }\end{array}$ & $\begin{array}{l}\text { Total No. of non- } \\
\text { marketable roots per plant }\end{array}$ & $\begin{array}{l}\text { Marketable root yield } \\
\text { per plant }(\mathbf{k g})\end{array}$ & $\begin{array}{l}\text { Non- marketable root } \\
\text { yield per plant }(\mathbf{k g})\end{array}$ \\
\hline \multicolumn{5}{|c|}{ Tillage method } \\
\hline Mound & $3.89^{\mathrm{a}}$ & $0.840^{\mathrm{a}}$ & $0.621^{\mathrm{a}}$ & $0.0307^{\mathrm{a}}$ \\
\hline Ridge & $3.87^{\mathrm{a}}$ & $0.853^{\mathrm{a}}$ & $0.729^{\mathrm{a}}$ & $0.0227^{\mathrm{a}}$ \\
\hline $\operatorname{LSD}(5 \%)$ & $\mathrm{NS}$ & $\mathrm{NS}$ & NS & NS \\
\hline SED & 0.20 & 0.17 & 0.05 & 0.01 \\
\hline \multicolumn{5}{|c|}{ P fertilizer $\left(\mathrm{kg}_{2} \mathrm{O}_{5} / \mathrm{ha}\right)$} \\
\hline Control & $3.20^{\mathrm{b}}$ & $0.567^{\mathrm{a}}$ & $0.508^{\mathrm{c}}$ & $0.0167^{\mathrm{a}}$ \\
\hline 30 & $4.30^{\mathrm{a}}$ & $0.800^{\mathrm{a}}$ & $0.570^{\mathrm{bc}}$ & $0.0200^{\mathrm{a}}$ \\
\hline 60 & $4.63^{\mathrm{a}}$ & $1.067^{\mathrm{a}}$ & $0.833^{\mathrm{a}}$ & $0.0267^{\mathrm{a}}$ \\
\hline 90 & $4.03^{\mathrm{a}}$ & $0.867^{\mathrm{a}}$ & $0.748^{\mathrm{ab}}$ & $0.0333^{\mathrm{a}}$ \\
\hline 120 & $3.23^{\mathrm{b}}$ & $0.933^{\mathrm{a}}$ & $0.717^{\mathrm{ab}}$ & $0.0367^{\mathrm{a}}$ \\
\hline LSD (5\%) & 0.68 & NS & 0.195 & NS \\
\hline SED & 0.32 & 0.26 & 0.09 & 0.01 \\
\hline Tillage $\times \mathbf{P}$ & NS & NS & NS & NS \\
\hline $\mathrm{CV}(\%)$ & 14.7 & 55.2 & 23.9 & 64.1 \\
\hline
\end{tabular}

NS - not significant from individual application; means having the same letter(s) in column, are not significantly different at $\mathrm{P}<0.05$ separated using the LSD

Table 5 Effects of tillage method and phosphorus fertilizer application on root yield per hectare and economic analysis of sweet potato.

\begin{tabular}{|lcc|}
\hline Treatments & Root yield per hectare (tonnes/ha) & Net benefit value (GHc) \\
\hline Tillage method & & $15,265.00^{\mathrm{b}}$ \\
\hline Mound & $11.48^{\mathrm{b}}$ & $19,150.00^{\mathrm{a}}$ \\
\hline Ridge & $14.17^{\mathrm{a}}$ & 3178.1 \\
\hline LSD $(5 \%)$ & 2.20 & 1512.7 \\
\hline SED & 1.04 & $13,654.00^{\mathrm{a}}$ \\
\hline P fertilizer $\left(\mathrm{kg} \mathrm{P}_{2} \mathrm{O}_{5} / \mathrm{ha}\right)$ & & $16,119.00^{\mathrm{a}}$ \\
\hline Control & $9.47^{\mathrm{c}}$ & $21,251.00^{\mathrm{a}}$ \\
\hline 30 & $12.18^{\mathrm{bc}}$ & $18,090.00^{\mathrm{a}}$ \\
\hline 60 & $15.82^{\mathrm{a}}$ & $16,924.00^{\mathrm{a}}$ \\
\hline 90 & $13.70^{\mathrm{ab}}$ & $\mathrm{NS}$ \\
\hline 120 & $12.97^{\mathrm{ab}}$ & 2391.8 \\
\hline LSD $(\mathbf{5 \%})$ & 3.48 & $\mathrm{NS}^{\mathrm{b}}$ \\
SED & 1.65 & 24.1 \\
\hline Tillage $\times$ P & $\mathrm{NS}$ & 22.4 \\
CV $(\%)$ & 22.4 & \\
\hline
\end{tabular}

NS - not significant from individual application; means having the same letter(s) in column, are not significantly different at $\mathrm{P}<0.05$ separated using the LSD

When ridges or mounds are constructed at a considerable height of $30 \mathrm{~cm}$, they provide favourable conditions around the planting zones that are essential for the normal growth of sweet potato (Traynor, 2005; Parwada et al., 2011). Proper seedbed preparation, ridging and mounding in the cultivation of root crops had been reported by FAO (2000) to loosen the soil, optimizes infiltration, enhances rooting depth and improves soil-water management. Certainly, Taylor \& Klepper (1978) emphasized that tillage systems that loosen the soil improve aeration, increase rooting depth and hence enable roots to proliferate and penetrate unexploited zones.

Although phosphorus fertilizer application rates had no significant effect on vine length, number of branches and vine girth at the two sampling periods (Table 2), the highest values for these parameters were obtained from plots treated with 60 $\mathrm{kg} \mathrm{P}_{2} \mathrm{O}_{5} / \mathrm{ha}$. These results are corroborates with the findings by Kareem (2013). In this study, vine length was observed to 
decrease at $\mathrm{P}$ application rates above $60 \mathrm{~kg} \mathrm{P}_{2} \mathrm{O}_{5} / \mathrm{ha}$. This is in agreement with reports of Rashid \& Waithaka (2009) who stated that vine production in sweet potato was not significantly affected by phosphorus and when applied at higher levels it led to the production of shorter vines. Despite this finding, phosphorus fertilizer application showed significant effect on number of leaves of sweet potato at 30 days after fertilizer application. This observed significant effect on number of leaves at 30 DAF could be as a result of the beneficial effect of $\mathrm{P}$ on the activation of photosynthesis and metabolic processes of organic compounds in plants which increase the growth of plants (Purekar et al., 1992).

Leaf production at 60 DAF did not show any significant treatment differences, which may be due to bulking of the storage roots at this stage. Van de Fliert \& Braun (1999) reported that between the $9^{\text {th }}$ week of the sweet potato growth cycle and maturity, vine growth reaches maximum. During this stage, foliage and vine density decrease since the plant uses most of the energy to fill the storage roots than to form and maintain vegetative parts. Also, it is this stage that most of the photosynthates in the vegetative parts are translocated to the roots for bulking.

4.2 Effect of tillage method and phosphorus fertilizer application on yield components of sweet potato

The non-significant effect of tillage methods on yield components (total number of roots, root yield per plant, total number of marketable and non- marketable roots, marketable and non- marketable root yield per plant and dry matter content of sweet potato) indicates that both ridging and mounding provided adequately favorable conditions for sweet potato growth and both loosened the soil, optimized infiltration and facilitated root expansion. This study's finding is similar to the report by Danquah et al. (2014) that yam yields were similar whether planted on ridges or mounds.

Yield components increased with increasing level of $\mathrm{P}$ fertilizer application from $0 \mathrm{~kg} \mathrm{P}_{2} \mathrm{O}_{5} / \mathrm{ha}$ to $60 \mathrm{~kg} \mathrm{P}_{2} \mathrm{O}_{5} / \mathrm{ha}$, but consequently decreased with application levels above $60 \mathrm{~kg}$ $\mathrm{P}_{2} \mathrm{O}_{5} / \mathrm{ha}$ (90 and $120 \mathrm{~kg} \mathrm{P}_{2} \mathrm{O}_{5} / \mathrm{ha}$ ) (Table 3 and 4). The observed significant effect of $\mathrm{P}$ fertilizer on yield components of sweet potato could be attributed to the low level of available native phosphorus in the soil (Table 1). According to Obigbesan et al. (1976), soils with less than $10 \mathrm{mg} / \mathrm{kg} \mathrm{P}$ are considered phosphorus deficient and may show positive response to phosphorus application. Significant effects of $\mathrm{P}$ fertilizer on sweet potato components of yield have also been reported by Hassan et al. (2005).

4.3 Effect of tillage methods and phosphorus fertilizer application on root yield of sweet potato.

Significantly higher root yield per hectare was observed in this study for ridging than for mounding (Table 5). Similar observation was reported by Ennin et al. (2003), these researchers reported $38 \%$ increases in sweet potato yield on ridges over mounds. Similarly, Brobbey (2015) concluded that planting sweet potato on ridges is better than mounds, as ridge planting resulted in greater growth and yield of the crop. The higher yield of sweet potato on ridging over mounding might be due to the higher plant population density on ridges that helped to suppress weeds and reduced competition for available nutrients between the crop and weeds. Evapotranspiration and weed infestation on mounding is high because of the greater soil surface area exposure; hence control of weeds is difficult. This might have contributed to the lower root yields on mound than on ridges (Ennin et al., 2009)

Significant effect of phosphorus fertilizer on sweet potato root yield confirmed that phosphorus is an important nutrient element for sweet potato production. This result is in line with Issaka et al. (2014) who reported a significant reduction in both tuber and vine production of sweet potato when $\mathrm{P}$ was omitted in a missing nutrients experiment, stressing the importance of $\mathrm{P}$ for sweet potato growth and yield. These results however contradicts with the report of MacDonald (1963) and FAO (2005) who stated that $\mathrm{P}$ does not seem to be important for sweet potato even though it is normally included in the fertilizer mixture, but if eliminated the yield of the crop will not be affected. The significant response of sweet potato to $\mathrm{P}$ fertilizer in the present study could be attributed to the low level of native phosphorus in the experimental site, thus indicating the need for phosphorus application. Root yield of sweet potato was depressed at application rates above $60 \mathrm{~kg}$ $\mathrm{P}_{2} \mathrm{O}_{5} /$ ha in this study indicating that the optimum rate of phosphorus fertilizer for sweet potato production is $60 \mathrm{~kg}$ $\mathrm{P}_{2} \mathrm{O}_{5} /$ ha. Tuber development of root and tuber crops has been reported by FAO (1994) to be suppressed by high levels of phosphorus in the soil.

4.4 Net benefit value of tillage methods and fertilizer treatments in sweet potato production

Ridging gave a higher average net return (GHc 19,150.00) than mounding (GHc 15,265.00). The application of $60 \mathrm{~kg} \mathrm{P} \mathrm{P}_{2} \mathrm{O}_{5} / \mathrm{ha}$ gave the highest average economic return ( $\mathrm{GHc} 21,251.00)$ while the control had the lowest (GHc 13,654.00) - the difference between the two was GHc 7,597.00.

\section{Conclusions and Recommendations}

According to the results of this study, tillage method did not significantly affect sweet potato growth, but significantly influenced the yield of the crop. In addition, sweet potato yield and its components were significantly affected by $\mathrm{P}$ fertilizer application hence producing a positive net return in sweet potato production. Amongst the tillage methods, higher net benefit return was observed for the ridging method. The $60 \mathrm{~kg}$ $\mathrm{P}_{2} \mathrm{O}_{5}$ /ha treatment was observed to be the optimum rate of phosphorus for sweet potato growth and yield. Based on the results of this study, the combination of ridge planting and application of $60 \mathrm{~kg} \mathrm{P}_{2} \mathrm{O}_{5} / \mathrm{ha}$ is recommended for sweet potation production in the semi deciduous forest zone of Ghana. Since the results obtained from this study were from 
one growing season, further study is recommended in order to confirm these findings.

\section{Acknowledgement}

The Authors wish to acknowledge the West Africa Agricultural Productivity Program of Sierra Leone (WAAPPSL) for supporting this work financially. We will also like to acknowledge Dr. Olupomi Ajayi (Africa Rice Research Co ordinator in Rokupr Agricultural Research Centre) for his constructive suggestions and inputs in this work. Finally, we appreciate the support given to us throughout the field work by the staff of the plantation section of the department of crop and soil sciences faculty of Agriculture Kwame Nkrumah University of Science and Technology.

\section{Conflict of interest}

Authors would hereby like to declare that there is no conflict of interests that could possibly arise.

\section{References}

Abd El-Baky MMH, Ahmed AA, Abd El-Aal FS, Salman SR (2009) Effect of Some Agricultural Practicies on Growth, Productivity and Root Quality of Three Sweet Potato Cultivars. Journal of Applied Sciences Research 5: 1966-1976.

Amoah FM (1997) The effect of number of nodes per cutting and potassium fertilizer on the growth, yield and yield components of sweet potatoes (Ipomoea batatas Poir). Ghana Journal of Agricultural Science 30: 53-62.

Anderson JM, Ingram JSI (1993) Tropical Soil Biology and Fertility: A handbook of Methods. Second edition. CAB International. Wallingford, UK. p. 37 available on http://www.sefs.washington.edu/classes.esrm.304/Spring2015/ module_soils_TropicalSoilBiology.pdf access on 29th April, 2016.

Asiamah RD (1998) Soils and Soil Suitability of Ashanti Region. UNESCO/FAO. Soil Research Institute. Technical Report No. 193. Kwadaso-Kumasi.

Berberich T, Takagi T, Miyazaki A, Otani M, Shimada T, Kusano T (2005) Production of mouse adiponectin, an antidiabetic protein, in transgenic sweet potato plants. Journal of Plant Physiology 162:1169-1176. http://dx.doi.org/10.1016/j.jplph.2005.01.009.

Bremner JM, Mulvaney CS (1982) Methods of soil analysis, part 2 chemical and microbiological properties Pp. 595-624.

Brobbey A (2015) Growth, yield and quality factors of sweet potato (Ipomoea batatas Lam) as affected by seedbed type and fertilizer application. M. Phil thesis submitted to Kwame Nkrumah University of Science and Technology, Kumasi.
CRI (2002) Crop Research Institute of Council for Scientific and industrial Resource, Ghana. Sweet potato: The crop of the future. Factsheet, November, 2002. Pp.6.

Cresswell HP, Hamilton (2002) Particle Size Analysis. In McKenzie NJ, Cresswell HP, Coughlan KJ (Eds.) Soil physical measurement and interpretation for Land Evaluation CSIRO publishing: Collingwood, Victoria. Pp 224 - 239.

Danquah EO, Issaka RN, Acheampong PP, Numafo $M$ and Ennin SA (2014). Mechanization, fertilization and staking options for environmentally sound yam production. African Journal of Agricultural Research, 9:2222-2230.

El Sayed Hameda EA, Saif El Dean A, Ezzat S, El Morsy AHA (2011) Responses of productivity and quality of sweet potato to phosphorus fertilizer rates and application methods of the humic acid. International Research Journal of Agricultural Science and Soil Science $1: 383-393$

Ennin SA, Dapaah HK, Asafu-Agyei JN (2003) Land preparation for increased sweet potato production in Ghana. Paper presented at the 13th Symposium of the International Society for Tropical Root Crops (ISTRC-World Branch), held from 10th-14th November, 2003 at Arusha, Tanzania, Pp. 14.

Ennin SA, Otoo E, Tetteh FM (2009) Ridging, a Mechanized Alternative to Mounding for Yam and Cassava Production. West African Journal of Applied Ecology 15: available on http://www.ajol.info/index.php/wajae/article/viewFile/49424/3 5757 access on 29th April, 2016.

FAO (1994) Tropical root and tuber crops: Production, perspective and future prospect. Food and Agricultural Organization (FAO).Plant Production and Protection Paper, Pp. 126-228.

FAO (2000) The state of food insecurity in the world 2000. ISBN 92-5-104479-1 Job No. X8200/E 36 pp.

FAO (2005) Fertilizer use by crop in Ghana. Food and Agriculture Organization of the United Nations (FAO). Produced by: Natural Resources Management and Environment Department, Pp 25.

FAO (2012) FAO production statistics. Available on http://www.fao.org/ assessed on 12/08/2013.

FAOSTAT (2006). Statistic Database (online) available online at http://apps.fao.org assessed on 12/08/2013.

Hanway JJ, Heidel H (1952) Soil analysis methods as used in Iowa state college, soil testing laboratory. Iowa Agriculture 54, 1-31, available on http://soiltesting.agron.iastate.edu/ access on $29^{\text {th }}$ April, 2016.

Hassan MA, El-Seifi SK, Omar EA, Saif EI-Deen UM (2005) Effect of mineral and bio-phosphate fertilization and foliar 
application of some micronutrients on growth, yield and quality of sweet potato (Ipomoea batata, L). 1- Vegetative growth, yield and tuber characteristics. Journal of Agricultural Science Mansoura University, 30: 6147-6166

Issaka RN, Buri MM, Ennin SA, Glover-Amengor M (2014) Effect of Mineral Fertilization on Sweet Potatoes [Ipomoea Batatas (L.)] Yield in the Sudan Savannah Agro-Ecological Zone of Ghana. International Journal of Agriculture Innovations and Research 2: 831-834.

Janssens MJJ (2001) Sweet Potato, Root and tubers. In: Raemaekers RH (Ed) Crop production in Tropical Africa. Directorate General for International Cooperation (DGIC) pp 205-221.

Kareem I (2013) Growth, Yield and Phosphorus Uptake of Sweet Potato (Ipomoea batatas) Under the Influence of Phosphorus Fertilizers. Research Journal of Chemical and Environmental Sciences 1:50- 55.

MacDonald AS (1963) Sweet potato with particular reference to the tropics. Field Crop Abstract 16:219-225.

Marschner H (1995) Mineral Nutrition of Higher Plants. $2^{\text {nd }}$ Ed. Academic Press, Harcourt Brace and Company, Publishers. London, New York, Tokyo, pp 864.

Metrological Department, Kwame Nkrumah University of Science and Technology (KNUST) (2014).

Obigbesan GO, Agboola AA, Fayemi AA (1976) Effect of potassium on tuber yield and nutrient uptake of yam varieties. Proceedings of the 4th Symposium of the International Society of Tropical Roots Crops. IDRC - CIAT, Columbia. Cock, Macintyre and Graham (Eds.), pp. 104-107.

Ojeniyi SO (1992) Food cropping, soil tillage and tillage research in sub-Saharan Africa. Paper presented at Inaugural Seminar of ISTRO, Nigeria Branch, NCAM, Ilorin, Nigeria.
Parwada C, Gadzirayi CT, Sithole AB (2011) Effect of ridge height and planting orientation on Ipomea batatas (sweet potato) production. Journal of Agricultural Biotechnology and Sustainable Development 3 : 72-76

Purekar PN, Singh RR, Deshmukh RD (1992) Plant Physiology and Ecology. $2^{\text {nd }}$ Ed. S Chand, and Company, New Delhi, India.

Rashid K, Waithaka K (2009) The effect of phosphorus fertilization on growth and tuberization of sweet potato, Ipomoea batatas L. ISHS Acta Horticulturae 153: IX African Symposium on Horticultural Crops http://dx.doi.org/10.17660/ActaHortic.1985.153.47.

Taylor HM, Klepper B (1978) The role of rooting characteristic in the supply of water to plants. Advances in Agronomy 30: 99-128. http://dx.doi.org/10.1016/S00652113(08)60704-X.

Traynor M (2005) Sweet Potato Production Guide for the Top End. Information Booklet, Northern Territory Government, 2006. Department of Primary industry, Fisheries and Mines. Crops, Forestry and Horticulture Division.

Van de Fliert E, Braun A (1999) Farmer field school for integrated crop management of sweet potato. Field guides and technical manual. International Potato Center. Lima, Peru. Pp.266.

Walkley A, Black IA (1934) An examination of the Degtjareff method for determining soil organic matter and a proposed chromic acid titration method. Soil Science 37:29-38

Were BA, Onkware AO, Gudu S (2003) Yield and storage quality of improved sweet potato (Ipomoea batatas (L) Lam.) cultivar in the lake Victoria Basin, Kenya. East African Agricultural and Forestry Journal 68 :197-204.

Woolfe JA (1992) Sweet potato: an untapped food resource. Cambridge University Press, Cambridge, UK. 